\title{
Apigenin exerts anticancer effects on human cervical cancer cells via induction of apoptosis and regulation of Raf/MEK/ERK signalling pathway
}

\author{
Jie Yang ${ }^{1}$, Jing $\mathrm{Fa}^{2}$, Bingxing $\mathrm{Li}^{3 *}$ \\ ${ }^{1}$ Women's Health, HealthCare Hospital of Linyi, ${ }^{2}$ Department of Gynaecology, Linyi City Tumor Hospital, ${ }^{3}$ Department \\ Obstetrical, Health Care Hospital of Linyi, Linyi, Shandong 276000, China
}

*For correspondence: Email: bingxingli@hotmail.com; Tel/Fax: 0086-138539881132

Sent for review: 17 December 2017

Revised accepted: 24 July 2018

\begin{abstract}
Purpose: To investigate the anticancer activity of apigenin on human cervical cancer cells.

Methods: The anti-proliferative effects of apigenin on HeLa cervical cancer cells were determined by 3(4,5-dimethylthiazol-2-yl)- )-2,5-diphenyltetrazolium bromide (MTT) and clonogenic assays, while its effect on apoptosis was assayed by DAPI and annexin V/PI double staining. Expression of proteins was assessed by immunoblotting.

Results: Apigenin exerted anticancer effects on HeLa cervical cancer cells with an IC50 of $15 \mu \mathrm{M}$, and also reduced the colony formation of HeLa cells. These antiproliferative effects were due to induction of apoptosis as indicated by DAPI and annexin V/PI staining. Apigenin altered Bax/Bcl-2 ratio, thereby triggering apoptosis, and also inhibited the Raf/MEK/ERK signalling pathway.

Conclusion: These results indicate that apigenin suppresses the growth of cervical cancer cells and may prove to be an important molecule for the treatment of cervical cancer.
\end{abstract}

Keywords: Cervical cancer, Apigenin, Apoptosis, Bax

\begin{abstract}
This is an Open Access article that uses a funding model which does not charge readers or their institutions for access and distributed under the terms of the Creative Commons Attribution License (http://creativecommons.org/licenses/by/4.0) and the Budapest Open Access Initiative (http://www.budapestopenaccessinitiative.org/read), which permit unrestricted use, distribution, and reproduction in any medium, provided the original work is properly credited.

Tropical Journal of Pharmaceutical Research is indexed by Science Citation Index (SciSearch), Scopus, International Pharmaceutical Abstract, Chemical Abstracts, Embase, Index Copernicus, EBSCO, African Index Medicus, JournalSeek, Journal Citation Reports/Science Edition, Directory of Open Access Journals (DOAJ), African Journal Online, Bioline International, Open-J-Gate and Pharmacy Abstracts
\end{abstract}

\section{INTRODUCTION}

Cervical cancer is one of the most reported cancers among women around the globe [1]. Annually, approximately 500,000 women are diagnosed with cervical cancer which constitutes about $9 \%$ of all newly-diagnosed cancers [1,2]. The conventional treatments for cervical cancer, such as radical hysterectomy and radiotherapy have a lot of adverse effects on the overall health of the patients $[3,4]$.
Naturally-occurring compounds have gained considerable attention in the treatment and prevention of various types of cancers [5-7]. Flavonoids constitute a diverse group of polyphenolics with a benzo- $\gamma$-pyrone skeleton and are widely distributed in the plant kingdom [8]. These are also frequently found in fruits, grains, green tea and other dietary supplements $[9,10]$. Numerous biological activities have been reported for flavonoids. These include antioxidant, antitumor, anti-inflammatory, antiallergenic and hepatoprotective effects $[11,12]$. 
Studies carried out previously suggest that diets rich in flavonoids are associated with decreased risk of cancers such as colon and prostate cancers $[13,14]$. Flavonoids such as flavopiridol, epigallocatechin gallate and quercetin have emerged as potent anticancer drug candidates, and some of them have already entered the stage of clinical trials [15]. Apigenin is a naturallyoccurring flavonoid known to possess many pharmacological properties such as antiinflammatory, antioxidant, and anticancer effects [15]. The present study was designed to investigate the anticancer activity of apigenin against HeLa cervical cancer cells.

\section{EXPERIMENTAL}

\section{Antiproliferative assay}

The viability of the cells was investigated by MTT assay. Cultured HeLa cervical cancer cells were grown at a density of $1.5 \times 10^{4}$ in 96 -well microtiter plates, and subjected to treatment with apigenin $(0-100 \mu \mathrm{M})$. This was followed by the addition of MTT solution to all the wells. The absorbance of the well plates was read at $570 \mathrm{~nm}$ in an ELISA plate reader.

\section{Clonogenic assay}

To assess the impact of Mukonal on the colonyforming potential of apigenin, the HeLa cells were harvested at exponential phase and counted using a hemocytometer. The platting of the cells was carried out at 200 cells /well. The plates were then kept at $37{ }^{\circ} \mathrm{C}$ for $48 \mathrm{~h}$ to permit cell adherence. This was followed by the addition of different concentrations of apigenin (0, 7.5, 15 and $300 \mu \mathrm{M})$. Following treatment with Mukonal, the cell plates were again incubated for 6 days, and thereafter washed with PBS and fixed with methanol. The HeLa cells were then stained with crystal violet and examined by microscopy.

\section{Apoptosis assay}

The HeLa cervical cancer cells were grown in 6well plates $\left(2 \times 10^{5}\right.$ cells per well) for $24 \mathrm{~h}$, and treated with apigenin at $0,7.5$ and $30 \mu \mathrm{M}$ doses for $24 \mathrm{~h}$. Thereafter, the cells were DAPI-stained to detect apoptosis by fluorescence microscopy as previously reported [9]. The percentage of apoptotic cells was determined using an FITCAnnexin V/PI Apoptosis Detection Kit as per the instructions of the manufacturer.

\section{Western blotting analysis}

The HeLa cervical cells were lysed with ice-cold hypotonic buffer. After estimating the protein contents in each of the cell extracts, the samples containing the proteins were loaded and separated on SDS-PAGE. Subsequently, transference of the gels to a nitrocellulose membrane and incubation with the primary antibody $(1: 1000)$ for $24 \mathrm{~h}$ at $4{ }^{\circ} \mathrm{C}$ were done. Thereafter the membrane was incubated with HRP-conjugated secondary antibody $(1: 1000)$ at $24{ }^{\circ} \mathrm{C}$ for about $1 \mathrm{~h}$. and the protein bands were visualised by enhanced chemi-luminescence reagent.

\section{Statistical analysis}

The assays were carried out in triplicate and the results presented as mean $\pm S D$. Data were analysed for significant differences using one way ANOVA and Tukey's test with the aid of GraphPad Prism 7 software. Values of $p<0.01$ were taken as indicating statistical significance.

\section{RESULTS}

\section{Anticancer effects of apigenin on HeLa cervical cancer}

The results of the MTT assay revealed that apigenin (Figure 1) displayed potent antiproliferative effect against HeLa cells in a dosedependent manner, with an $\mathrm{IC}_{50} 15 \mu \mathrm{M}$ (Figure 2). Furthermore, it was revealed that apigenin treatment reduced the number colonies formed by viable HeLa cells in a dose-dependent fashion (Figure 3), indicating its anti-proliferative effects.

\section{Apigenin caused apoptosis in cervical cancer HeLa cells}

After treatment with the different concentrations of apigenin, apoptosis was determined by DAPI staining. The results showed that apigenin caused apoptosis in a concentration-dependent pattern, as evident from the greater density of white color nuclei (Figure 4). The apoptotic ell populations were further estimated by annexin V/PI double staining. The results showed that the apoptotic cell populations increased from $2.35 \%$ in the control group, to $38.54 \%$ at $30 \mu \mathrm{M}$ apigenin (Figure 5). In addition, apigenin increased the expression of Bax, and decreased the expression of Bcl-2 (Figure 6).

\section{Apigenin inhibits the Raf/MEK/ERK signalling pathway}

The effect of apigenin on the Raf/MEK/ERK signal transduction pathway was also investigated and the results revealed that apigenin inhibited the (phosphorylated) p-MEK and p-ERK dose dependently (Figure 7). 
However, no effects were observed on MEK and ERK.<smiles>O=c1cc(-c2cccc(O)c2)oc2cc(O)cc(O)c12</smiles>

Figure 1: Chemical structure of apigenin

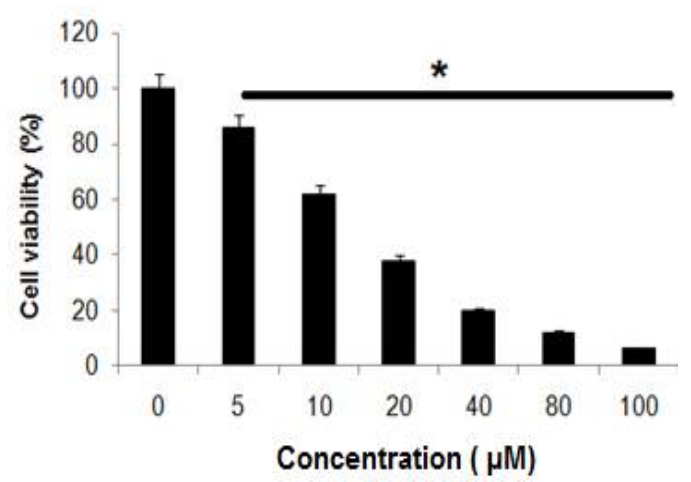

Figure 2: Effect of apigenin on the viability of HeLa cells. The experiment was performed in three replicates. Values are mean \pm SD $\left({ }^{*} p<0.01\right)$

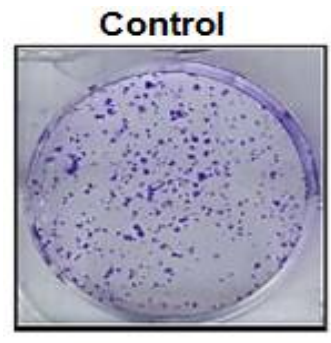

$15 \mu \mathrm{M}$
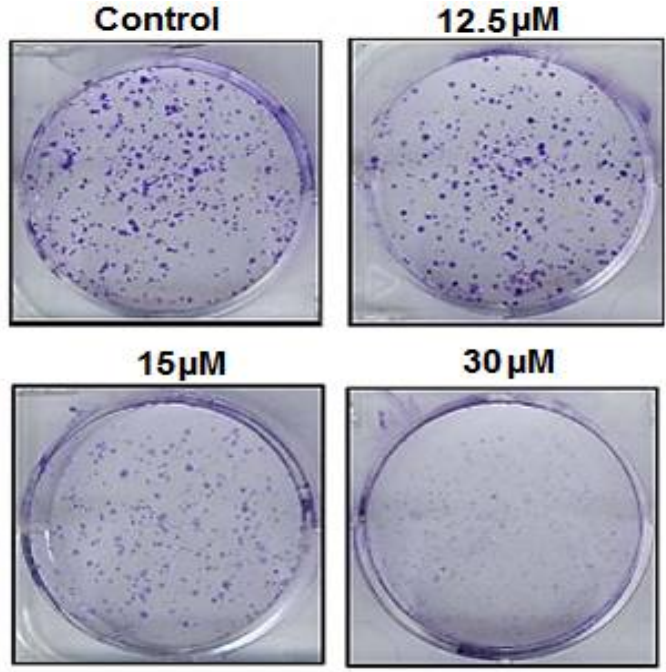

$30 \mu \mathrm{M}$

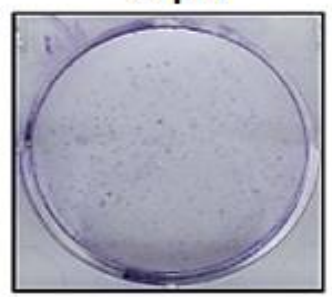

Figure 3: Dose-dependent effect of apigenin on the colony formation potential of HeLa cells. The experiment was performed in three replicates

\section{DISCUSSION}

Cervical cancer is one among the most commonly diagnosed cancers in women the world over. Indeed, it is estimated that about 500,000 women are diagnosed with cervical cancer annually $[1,2]$. The treatment options for cervical cancer are limited and inefficient, and they are associated with a lot of adverse effects.
Hence, there is need for the exploration of new molecules for the treatment of cervical cancer [2]. Apigenin is a naturally-occurring flavonoid reported to possess many biological activities such as antioxidant and anti-tumor activities [15].
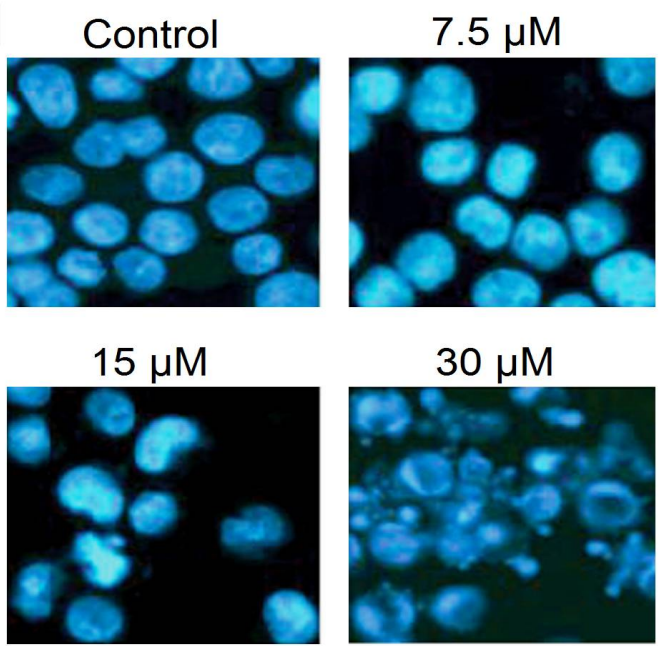

Figure 4: Effect of apigeninon apoptosis in HeLa cancer cells as evident from the DAPI staining. The experiment was performed in three replicates
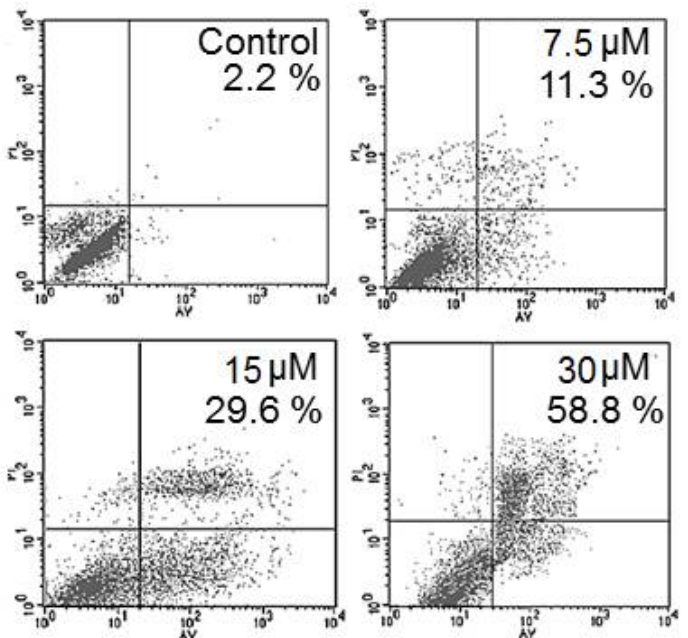

Figure 5: Effect of different doses of apigenin on percentage of apoptotic HeLa cancer cells, as determined using annexin V/PI staining. The experiment was performed in three replicates

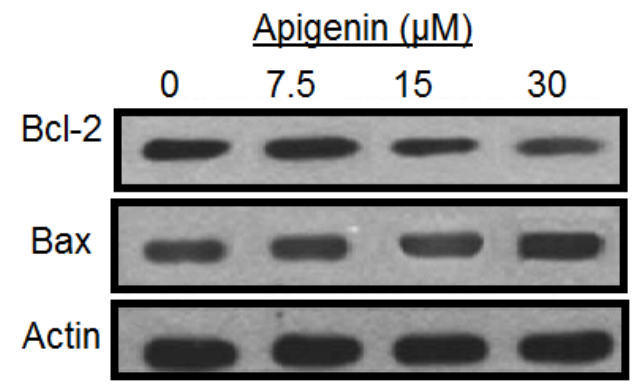

Figure 6: Effect of indicated doses of apigenin on Bax and $\mathrm{Bcl}-2$ proteins as revealed through western blots. The experiment was performed in three replicates 


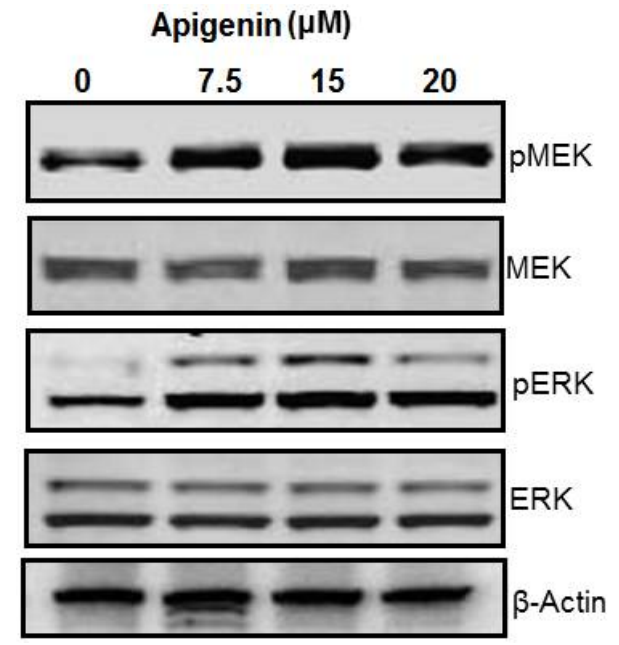

Figure 7: Effect of indicated apigeninon Raf/MEK/ERK signalling pathway

In this context, the anticancer activity of apigenin against Hela cervical cancer cell line was evaluated. It was observed that apigenin exhibited potential growth-inhibitory effects on HeLa cells, as evident from proliferation assay. The results of MTT assay were further complimented and validated by the colony formation assay. As it has been shown previously, several anticancer drugs trigger antiproliferative effects through induction of apoptosis. For example, the anticancer drugs, such as taxol have been shown to activate apoptotic cell death and cause DNA damage [1618]. To assess if apigenin triggers apoptosis in HeLa cells, the apigenin-treated cells were DAPIstained. It was revealed that apigenin induced apoptotic cell death concentration-dependently.

Furthermore the results of annexin V/PI staining revealed that the percentage of the apoptotic cell populations increased with increase in the concentration of apigenin which was concomitant with the enhancement of Bax expression and decline in $\mathrm{Bcl}-2$ expression. The expressions of $\mathrm{Bax}$ and $\mathrm{Bcl}-2$ shift the cells towards apoptosis. Previously it has been reported that the Bax/Bcl2 ratio is a vital factor for the induction of apoptosis [19]. The Raf/MEK/ERK signalling pathway is involved in the proliferation of cancer cells, and drugs that target this pathway are considered important [20]. In the present study it was observed that apigenin downregulated the expression of $\mathrm{p}$-MEK and $\mathrm{p}$-ERK in a concentration-dependent manner. These inhibitory effects of apigenin on cervical cancer cell proliferation may prove beneficial in the treatment and management of cervical cancers.

\section{CONCLUSION}

The results obtained in this study indicate that apigenin exerts anticancer effects on cervical cancer cells via induction of apoptosis and inhibition of Raf/MEK/ER signalling pathway. This confirms the potential of apigenin as anticancer agent. Thus, this flavonoid may be utilised as a lead molecule in the development of anticancer chemotherapy.

\section{DECLARATIONS}

\section{Acknowledgement}

The corresponding author acknowledges the Department Obstetrical, Health Care Hospital of Linyi, Linyi, Shandong 276000, China for providing some of the facilities.

\section{Conflict of interest}

No conflict of interest is associated with this work.

\section{Contribution of authors}

The authors declare that this work was done by the authors named in this article and all liabilities pertaining to claims relating to the content of this article will be borne by them. Jie Yang and Jing Fa performed all the experiments under the supervision of Bingxing Li. Bingxing Li designed the study.

\section{REFERENCES}

1. Jemal A, Bray F, Center MM, Ferlay J, Ward E, Forman $D$. Global cancer statistics. CA: a cancer journal for clinicians. CA Cancer J Clin2011; 61(2): 69-90.

2. Cadron I, Van Gorp T, Amant F, Leunen K, Neven P, Vergote I. Chemotherapy for recurrent cervical cancer. Gynecol Oncol 2007; 31; 107: S113-S118.

3. Engelman JA. Targeting PI3K signalling in cancer: opportunities, challenges and limitations. Nat Rev Cancer 2009: 9: 550-562.

4. Romashkova JA, Makarov SS: NF-kappa $B$ is a target of $A K T$ in anti-apoptotic PDGF signalling. Nature 1999; 401:86-90.

5. Hafeez BB, Siddiqui IA, Asim M, Malik A, Afaq F, Adhami VM, Saleem M, Din M, Mukhtar H. A dietary anthocyanidindelphinidin induces apoptosis of human prostate cancer PC3 cells in vitro and in vivo: involvement of nuclear factor- $K B$ signaling. Cancer Res, 2008; 68(20): 8564-8572.

6. Hafeez BB, Fischer JW, Singh A, Zhong W, Mustafa A, Meske L, Sheikhani MO, Verma AK. Plumbagin inhibits prostate carcinogenesis in intact and castrated PTEN 
knockout mice via targeting $P K C \varepsilon$, Stat3, and epithelialto-mesenchymal transition markers. Cancer Prev Res 2015; 8(5): 375-386.

7. Lall RK, Adhami VM, Mukhtar H. Dietary flavonoid fisetin for cancer prevention and treatment. Mol Nutr Fod Res Toxicol 2006; 217: 213-220.

8. Schwinn KE, Davies KM. Flavonoids. Annual Plant Reviews. 2018; 15:92-149.

9. Cook NC, Samman S. Review: flavonoids-chemistry, metabolism, cardioprotective effects and dietary sources, J Nutr Biochem1996; 7(2): 66-76.

10. Rice-evans CA, Miller NJ, Bolwell PG, Bramley PM, Pridham JB. The relative antioxidant activities of plantderived polyphenolic flavonoids. Free Rad Res 1995; 22(4): 375-383.

11. Kanadaswami $C$, Lee $L T$, Lee PP, Hwang JJ, Ke FC, Huang YT, Lee MT. The antitumor activities of flavonoids. In vivo 2005; 19(5): 895-909.

12. Parhiz $H$, Roohbakhsh A, Soltani $F$, Rezaee R, Iranshahi M. Antioxidant and anti-inflammatory properties of the citrus flavonoids hesperidin and hesperetin: an updated review of their molecular mechanisms and experimental models. Phytotherap Res 2015; 29(3): 323-331.

13. Ravindranath $\mathrm{MH}$, Muthugounder $\mathrm{S}$, Presser $\mathrm{N}$, Viswanathan S. Anticancer therapeutic potential of soy isoflavone, genistein. In Complementary and Alternative Approaches to Biomedicine 2004; 121-165. Springer, Boston, MA.
14. Wang HK. The therapeutic potential of flavonoids. Expert Opin Investig Drugs 2000; 9(9): 2103-2119.

15. Bouzaiene NN, Chaabane F, Sassi A, Chekir-Ghedira L, Ghedira K. Effect of apigenin-7-glucoside, genkwanin and naringenin on tyrosinase activity and melanin synthesis in B16F10 melanoma cells. Life Sci 2016; 144: 80-85.

16. Azuma M, Tamatani T, Ashida Y, Takashima R, Harada $K$, Sato M. Cisplatin induces apoptosis in oral squamous carcinoma cells by the mitochondria-mediated but not theNF-kappa $\beta$-suppressed pathway. Oral Oncol 2003; 39: 282-289.

17. Yoneda K, Yamamoto T, Osaki T. p53- and p21independent apoptosis of squamous cell carcinoma cells induced by 5-fluorouracil and radiation. Oral Oncol 1998; 34: 529-537.

18. Ferreira CG, Epping M, Kruyt FA, Giaccone G. Apoptosis target of cancer therapy. Clin. Cancer Res 2002; 8: 2024-2034.

19. Raisova M, Hossini AM, Eberle J, Riebeling C, Orfanos CE, Geilen CC, Wieder T, Sturm I, Daniel PT. The $\mathrm{Bax} / \mathrm{Bcl}-2$ ratio determines the susceptibility of human melanoma cells to CD95/Fas-mediated apoptosis. J Investigative Dermatol 2001; 117(2): 333-340.

20. Roberts PJ, Der CJ. Targeting the Raf-MEK-ERK mitogen-activated protein kinase cascade for the treatment of cancer. Oncogene 2007; 26(22): 3291-310. 